\title{
The Role of Commitment in the Relationship between Components of Organizational Culture and Intention to Stay
}

\author{
Smart A. Sarpong ${ }^{1,2, *(\mathbb{D}}$, Mary Safowah Akom ${ }^{3}\left(\mathbb{D}\right.$, Emelia Kusi-Owusu $^{3}$, Irene Ofosua-Adjei ${ }^{1}(\mathbb{C}$ and \\ Youngjo Lee ${ }^{2, * \mathbb{B}}$
}

1 Centre for Social Science Research, Kumasi Technical University, Kumasi 039-5028, Ghana; eneri865@gmail.com

2 Department of Statistics, Seoul National University, Seoul 08826, Korea

3 Staff of the Registary, Kumasi Technical University, Kumasi 039-5028, Ghana; maamesafowah@gmail.com (M.S.A.); emekiel77@gmail.com (E.K.-O.)

* Correspondence: smart.asarpong@kstu.edu.gh (S.A.S.); youngjo@snu.ac.kr (Y.L.); Tel.: +233-(0)244028091 (S.A.S.)

Citation: Sarpong, S.A.; Akom, M.S.; Kusi-Owusu, E.; Ofosua-Adjei, I.; Lee, Y. The Role of Commitment in the Relationship between Components of Organizational Culture and Intention to Stay. Sustainability 2021, 13, 5151. https://doi.org/10.3390/su13095151

Academic Editor: Andrea Pérez

Received: 2 March 2021

Accepted: 26 April 2021

Published: 5 May 2021

Publisher's Note: MDPI stays neutral with regard to jurisdictional claims in published maps and institutional affiliations.

Copyright: (c) 2021 by the authors. Licensee MDPI, Basel, Switzerland. This article is an open access article distributed under the terms and conditions of the Creative Commons Attribution (CC BY) license (https:// creativecommons.org/licenses/by/ $4.0 /)$.

\begin{abstract}
For an institution to be classified as one of the best or worst, it largely depends on the people behind it. An institution's human resource is, therefore, seen as its most important asset. This paper investigates the role of employee commitment in linking some components of organizational culture to employee intention to stay. Components of organizational culture investigated in this paper include work environment, reward system, work environment, and leadership. Data for this study was obtained through a survey of staff of Kumasi Technical University in Ghana with the help of a questionnaire modified and simplified from pre-validated instruments proposed by early researchers. A total of 216 responses were sought from the permanent staff of the university (teaching, non-teaching). Analysis of the study was completed using LISREL software. Parameter estimates of the best-fitting model reveal that commitment mediates the relationship between three components of organizational culture (i.e., reward system, work environment, and leadership) and employee intention to stay. An important conclusion of this study is that a committed employee still requires a well-structured reward system, conducive work environment, and quality leadership from management of institutions to inform their decision to remain in the service of that organization or otherwise.
\end{abstract}

Keywords: mediation; commitment; employee; organizational culture

\section{Introduction}

Human resource is the most useful asset of any firm or institution. Very good workers are the hands behind the best institutions, and bad workers result in inept institutions. Encouraging workers to do their very best, even under difficult situations, is perhaps the most lasting but tricky challenge for managers and institutional leaders [1]. Owing to this, workforce management has gained serious consideration among institutions across the globe [2]. Since the effect of any mismanagement of the workforce may affect the quality of training for prospective graduates, many tertiary educational institutions in Ghana have started treating staff retention and staff commitment as an integral concept in the curriculum rather than its usual approach to staff management issues [3].

According to Klein, Molloy, and Cooper [4], if an employee exhibits sincere loyalty to his/her institution of work, such an employee is considered committed. Commitment is also measured as a worker's willingness to invest even more time and effort in their institution, the extent of agreement between the institution's aims and values and the worker's, and the worker's readiness to continue working for the institution. Some studies $[5,6]$ have conceived commitment in several ways, but, for the purposes of this study, commitment is conceived as an attraction that draws a person closer to a target or a course 
of action that becomes useful to that target $[7,8]$. Another useful concern in commitment research concerns increasing interest analogous workplace commitments $[8,9]$, such as that which a staff of one institution extends to sister institutions (e.g., worker associations, professional bodies, etc.) [10], human resource (e.g., Team leaders, supervisors, and team members, etc.) [11], and actions and inactions of institutions (e.g., Values, aims, visions, and programs) [12]. It is interesting to observe that all the forms of commitments were seen to significantly influence employees, and in most instances, the entire institution as well.

Present and past governments of Ghana have taken many steps to strengthen the education sector to support the country in becoming a leading education hub in sub-Saharan Africa. One such key player in achieving this goal is Kumasi Technical University. However, when a committed lecturer leaves the employment of the university, the institution will be burdened with lost skills and experience. Another idea that is relevant to this study, advanced by $[13,14]$, is that although an institution may have its "own unique culture", there are also individual subcultures linked to different management styles, especially in larger institutions. The paper, therefore, seeks to find out the mediation role of employee commitment in linking components of institutional culture and employee intention to stay; with evidence from Kumasi Technical University in Ghana.

To the best of the authors' knowledge, no research focusing on institutions of higher learning in Ghana has tried to directly establish such mediation between the two constructs (components of organizational culture and employee intention to stay). Apart from [15], who studied three of our four determinants using a multidimensional measure for culture, all other researchers cited in this paper studied a maximum of two variables at a time. The context of Ghana and its relevance to national and regional organizations also distinguishes this paper from other similar articles. By attempting to offer logically consistent explanations of the linkages between the determinants of institutional culture, employee commitment, and intention to stay, this paper contributes to knowledge and literature in the subject area. Recommendations of this paper may also serve as an important step toward stimulating further investigations in this area.

The second section of this paper sets the context of the study and reviews important themes such as employee commitment, institutional culture components, and employee intention to stay. In this section, a clear theoretical framework and specific hypotheses are also developed. The third section presents the methods used in data collection and data analysis. Analysis of results and interpretation of the mediatory role of employee commitment on institutional culture components and employee intention to stay, recommendations of this research, and conclusions are discussed in sections four and five.

\section{Literature Review and Hypotheses Development}

\subsection{Institutional Sustainability}

Components of organizational culture (environment, reward systems, leadership, and organizational policy), and commitment are important drivers of organizational sustainability [16]. Organizational heads are required to relate with their workers in a manner that will promote organizational sustainability [17]. Norton et al. [18] concluded that leadership encourages an employee to be innovative and creative within a conducive work environment. The work environment was also found to be an instrument used to elicit desirable outcomes from employees [19]. Rewards must be extended to employees in both tangibles and intangibles. Such rewards become a reflection of the culture and values of the organization [20]. It is, therefore, conclusive that work environment, reward systems, leadership, and organizational policy, and employee commitment should be the focus of institutional managers as they aim for sustainability.

The many issues that constitute components of organizational culture, leadership style, reward and recognition culture, work environment, and organizational policy, among others, have an immense influence on the level of commitment [21]. In his context, the worse the superior-subordinate relationships become, the lower the employee commitment and the intention to stay. This view was also supported by [22]. In a very recent study on 
mineworker commitment, [23] established that cultural emotion and its dimensions played a significant positive role in promoting work commitment. Along with other factors such as teamwork, adaptability, promotion, etc., studies have established that a friendlier work environment, rewards and recognition systems that encourage, and institutional policies that are fairly and equally applied to all are associated with higher commitment of staff and a greater the intention to stay $[15,24,25]$.

\subsection{Theoretical Framework}

Many frameworks have been developed for the discussion of organizational culture. For example, [26] categorized organizational culture as something that an organization has as opposed to something that an organization is. Many researchers who studied how organizations differ in terms of focus have relied on Smircich's categorization [27,28]. The main goal of such studies has been to differentiate the more effective elements of culture from the less effective relative to the institution under study [29]. Describing the understanding of the staff of such institutions and their level of association with the cultural elements may be alternative research goals [30]. This study adopts and modifies the ethical corporate model of [31] with the inclusion of the element of reward.

Many managers of organizations have considered corporate culture as essential to workforce management. Schwartz [31] opined that corporate culture is an intangible phenomenon that is very difficult to manage or manipulate. In his ethical corporate model, adapted to this current study, Schwartz addresses the components of corporate culture under various subtitles: Work Environment and Organizational Policy (under Core Ethical Values) and Leadership (under Ethical Leadership). For example, [32] outlined some key ingredients of a cordial working environment. They include trustworthiness, mutual respect, shared responsibility, fairness, and caring for one another.

One major pillar of the ethical corporate culture model concerns leadership. According to [33], leadership entails the "tone" of an institution as established by top management. In effect, members of staff observe and follow the behavior of their top managers. Leadership is, therefore, supposed to be the main source of guidance to any organization [34]. Other researchers have established that because leadership has a direct impact on any organization, corporate culture should center around leadership [35]. Again, the corporate culture model suggests that organizations must have a well-documented policy that must be known to all members of the organization [31]. This, according to [36], brings clarity to the specific values that must be incorporated and such systems that are being measured, rewarded, and disciplined; for which staff must pay attention to.

The reward was inserted to modify the ethical corporate culture model because, while culture defines the values and attitudes that influence employee behavior, the intrinsic element that an employee can maintain, transmit, or influence is the organization's reward system [37]. As per their study, reward systems represent one of the most powerful elements of organizational culture as it defines the employer-employee relationship and other terms and conditions, as well as the resulting benefits to the employee upon satisfactory performance.

This study modifies a corporate culture model with four components as shown in Figure 1.

\subsection{Leadership and Employee Retention}

The leadership style of every organization is very essential in the retention of employees. In employee turnover retention, the relationship that exists between a worker and a supervisor plays an important role. According to [38], the perception of every employee regarding the organization is significantly influenced by their relationship with the supervisor. Employee turnover retention is likely to favor the organization if supervisors have a good relationship with subordinates, and support and communicate openly [39]. A study conducted on hospital directors determined that there was an essential link between leadership productivity and behavior, the commitment of the staff in the organization, and the 
satisfaction of workers [40]. In [13,14] it is argued that although an institution may have its "own unique culture", there are also individual subcultures linked to different management styles, especially in larger institutions. Brunetto and Farr-Wharton [41] also expressed that the level of job satisfaction among staff increases with supervision by immediate managers. Fang et al. [42] asserted that the leadership style of every organization can have a positive effect on work satisfaction and the commitment of the staff of that organization, as well as work performance. Ontario [43] submits that associates usually leave the leaders and not the job so they require the support of leaders. Absenteeism and turnover intention rates would decrease if employees are valued in the institution and highly prioritized in decision making, actively take part in organizational goals, show productive behavior in the workplace, and are involved in all aspects of the job.

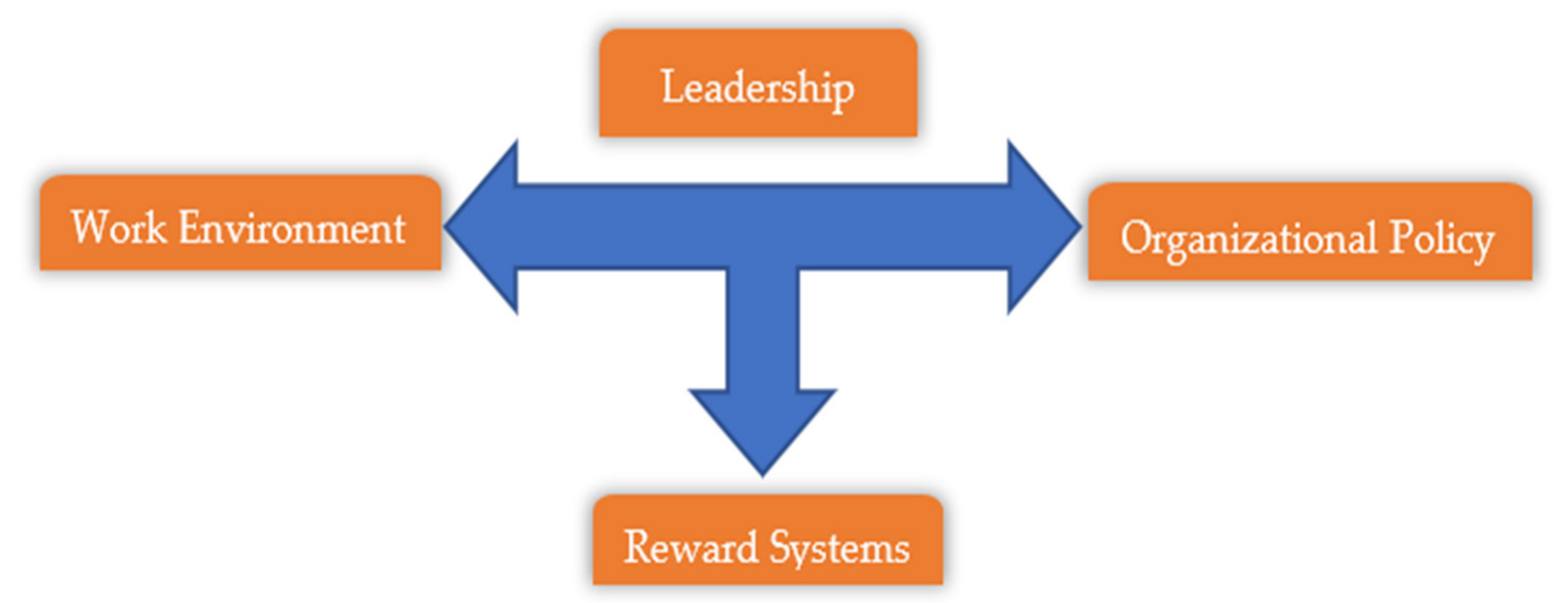

Figure 1. Modified ethical corporate culture model.

According to [44], an effective way of retaining talented employees is maintaining a healthy working environment by promoting leadership support as these well-skilled employees may easily obtain new jobs with good positions. Freyermuth [45] also states that organizations must build the working environment of their employees and groom their leaders to provide them with the necessary support. To enhance the abilities of the organization and convince associates to stay, the institutions should provide opportunities that test the capabilities of associates and promote their level of performance.

\subsection{Work Environment and Employee Retention}

Miller et al. [46] submit that employees benefit from organizations that provide a sense of belonging. In employment retention, the working environment is considered an important factor [47]. Wells and Thelen [48] also express that associations that have liberal human asset approaches have generally excellent opportunities to fulfill and retain associates by providing sound control of work and an appropriate level of privacy in their working environment, which would lead to long-term enhancement of motivation within the organization.

Hytter [49] asserts that the working environment should be discussed from an industrial perspective, focusing on aspects such as exposure to dangerous substances, noise, and heavy lifts, etc. The elements of a working environment in service sectors are directly different from those in production sectors. According to [50], the service sector deals with clients or consumers directly. The type of communication is based on the type of job or kind of business; it may be less or more. The communication between consumers and associates has moved from a physical dimension to a psychological dimension. The psychological work environment consists of workload, support, decision, stressors, latitude, and decision-making. 


\subsection{Reward and Recognition}

According to [44], the literal definition of reward is the number of benefits, pay or equivalents, an associate receives in return for the service rendered to a firm. Staff commitment and customer loyalty are enhanced by recognition from bosses, co-workers, and team members [51]. In 2002, a global consulting firm named Watson Wyatt conducted a survey in the USA among 12750 associates at various levels of jobs in all sectors in the industry. This was conducted to determine the attitudes of various employees towards the workplace and their superiors. The outcome of the investigation stated that recognition is essential for most workers. Rewards are given in different forms, especially in the business environment, e.g., free trips, free merchandise, recognition, cash bonuses, and awards. Rewards are important because they make an enduring impression on employees and assure them that they are highly valued in the firm [44].

\subsection{Organizational Policy}

Policies formulated by organizations must ensure just, fair, equitable, and ethical employee treatment within the organization. The Oxford dictionary defines justice as the act of being fair or just. Chew and Chan [52] opines that organizational policy provides a sense of direction and growth for employees. According to [53], a modernized business allows the participation of employees at all levels in decision-making and keeps them informed about all important activities and matters. Anything short of that is seen to be unfair and an injustice, which can breed a lack of commitment as well as negatively affect employee intention to stay. According to [54], for an institution to create a sense of belonging among employees, employees must be involved in decision-making. Doing this would create a good congenial working environment that would build a good employeremployee relationship.

According to [55], every firm must formulate its own rules and promote their implementation among associates. Fairness in organizational culture has been given much significance by social psychological researchers. The equity theory states that most employees make a comparison of their best input (time and effort) against their best output (pay and status) with other employees to judge whether or not they are treated fairly. Employees respond to this unfair or fair distribution of outcomes with attitudes that are satisfactory or unsatisfactory. When employees become satisfied or dissatisfied with their work, it leads to behavioral intentions and decisions, which determine if they continue working or leave [56].

\subsection{Hypotheses}

Main Hypothesis $\left(\mathbf{H}_{1 \mathbf{a}(1-4)}-\mathbf{H}_{1 \mathbf{b}}\right)$. Employee commitment mediates the link between components of organizational culture and intention to stay.

Specific Hypothesis

Hypothesis $\mathbf{1}\left(\mathbf{H}_{1 \mathbf{a} 1}-\mathbf{H}_{\mathbf{1 b}}\right)$. Employee commitment mediates the link between leadership and intention to stay.

Hypothesis $\mathbf{2}\left(\mathbf{H}_{1 \mathbf{a} 2}-\mathbf{H}_{1 \mathbf{b}}\right)$. Employee commitment mediates the link between the working environment and intention to stay.

Hypothesis $\mathbf{3}\left(\mathbf{H}_{1 \mathrm{a} 3}-\mathbf{H}_{1 \mathbf{b}}\right)$. Employee commitment mediates the link between the reward system and intention to stay.

Hypothesis $\mathbf{4}\left(\mathbf{H}_{\mathbf{1 a} 4}-\mathbf{H}_{\mathbf{1 b}}\right)$. Employee commitment mediates the link between organizational policy and intention to stay. 


\section{Method}

\subsection{Data Source and Measurement}

The study population comprises the staff of Kumasi Technical University. The analysis is based on primary data obtained from staff through a structured questionnaire. The questionnaire for employee retention and components organizational culture used in this study is a modified and simplified version of pre-validated instruments proposed by [57], and [58], while the questionnaire for employee commitment was simplified from the original commitment scale items [59]. The researcher delivered the questionnaire by hand and participants were allowed to complete the structured questionnaire. No identifiers were needed and the completion of the survey questionnaire was anonymous and voluntary.

Using a sampling factor of 50 percent of total staff, 237 staff were selected to participate in this study, with respondents chosen by a probability stratified sampling technique with a specific interest in the permanent staff of the university (teaching, non-teaching). The recovery of the complete 216 responses translates to a 91.3 percent response rate. Table 1 reflects the population and sample distribution. Sample representativeness was addressed adequately in the stratification process. The possibility of measurement errors and interviewer bias, among others, were adequately dealt with through a strict data editing and entry regime that was adhered to throughout the study period. Prior notification of the study and callbacks were the two main strategies employed to achieve the recorded response rate.

Table 1. Population and sample distribution.

\begin{tabular}{ccccc}
\hline Stratum & Population & Sample & Response & Response \% \\
\hline Teaching & 314 & 157 & 143 & 91.1 \\
Non-Teaching & 160 & 80 & 73 & 91.3 \\
Total & 474 & 237 & 216 & 91.1 \\
\hline
\end{tabular}

\subsection{Ethical Approval}

Ethical approval was sought and obtained from the University Research Ethics Committee. Informed consent was sought from the Staff participants of this study. The right of participants to decline participation was strictly emphasized and respected throughout the study data collection. Data has been and will continue to be treated with absolute confidentiality.

\subsection{Variables Measured}

The dependent variable for this study is employee intention to stay. In other to capture the respondent's perceived intention to stay in the employment of the university, four sevenpoint Likert scale items ( 1 = Strongly Disagree; $7=$ Strongly Agree $)$ were used. The survey items through which respondents expressed their level of agreement or disagreement included the following: I plan to work at my present job for as long as possible; I am most certainly going to look for a new job in the very near future; I plan to stay in this job for at least two to three years; I would not like to quit this job.

Independent variables for this study include organizational culture components such as leadership, organizational policy, reward systems, and work environment. Participants completed three seven-point Likert scale items ( 1 = Strongly Disagree; 7 = Strongly Agree) concerning the reward system at the university. The survey asked respondents their extent of agreement or disagreement with the following statements: staff are positively recognized when they come up with high-quality work; this university pays a better reward package compared to other similar organizations; this university cherishes individual excellence over teamwork.

For organizational policy, the survey items included the following: policies and procedures of the university have been helpful; progress procedures for monitoring the 
planned objectives of the university are reviewed periodically; the current university management structure promotes our way of doing things; this university has a definite vision/mission to guide its goals and aspirations. On work environment, the survey asked respondents their extent of agreement or disagreement with the following statements: there is a balance between my working life and my family life; in all, I see this university as a peaceful place of work; the welfare of staff is regarded as the number one priority of the university; as per my core task, the immediate physical working conditions are sufficient. Under leadership, the survey items include: the leadership practices in this university propel me to become a high-performing staff member; leadership practices of this university are consistent with my values; staff of this university are well-informed on issues that are deemed very important to them.

Employee commitment is used in this study as a mediating variable and four sevenpoint Likert scale items ( 1 = Strongly Disagree; 7 = Strongly Agree) were used to assess employee commitment in the university. The survey items include the following: I have a strong feeling of belonging at this university; I am very ready to give my all to help this university succeed; I am always eager to let people know that I am part of this University; I am always concerned about the future of this university.

\subsection{Data Analysis}

Analysis of the study was completed using LISREL software. Cronbach's alpha coefficient was used in determining the internal consistency of our instrument. Full structural equation modeling mediation analysis was carried out using LISREL software. The entire analysis focuses on building a mediation model that confirms the relationships between variables in the theoretical framework. SEM is seen as the most suitable method in this study since it is a statistical method that allows complex relationships with multiple dependent and independent latent and observed variables.

\section{Results and Discussion}

\subsection{Assessment of the Measures}

Table 2 presents the demographic characteristics of respondents while Table 3 shows the inter-variable correlation. The measures of both organizational culture and employee commitment were positively correlated with the measures of intention to stay, with correlation coefficients ranging from 0.397 to 0.533 for the relationship between reward system and the rest of the measures (organizational policy $=0.397$, work environment $=0.362$, leadership $=0.393$, employee commitment $=0.533$, and intention to stay $=0.420$ ). The correlation coefficients for the relationship between organizational policy and the rest range from 0.551 to 384 while that for the work environment and the others range from 0.335 to 0.422. All in all, a moderate to a strong positive correlation between the measured variables indicated their ability to improve when one variable is improved and vice-versa.

\subsection{Reliability and Validity of the Constructs}

The internal consistency of the constructs was assessed by their Cronbach alpha (CA) reliability and reported in Table 4 . All constructs had a good internal consistency ranging from 0.744 for reward systems, 0.871 for organizational policy, 0.839 for the work environment, 0.786 for leadership style, 0.910 for employee commitment, and 0.866 for intention to stay. We followed the Anderson and Gerbing [60] procedure in testing the validity of the constructs. Variance extracted is seen to be higher than their analogous inter-construct squared correlations [57] indicating their uniqueness and, hence, supporting the discriminant validity of each construct. The confirmatory factor analysis model for all six factors also fits the data well; $\chi^{2}(\mathrm{DF})=288.47(215) ; \chi^{2} / \mathrm{DF}=4.001 ; \mathrm{RMSEA}=0.049$; $\mathrm{NNFI}=0.926 ; \mathrm{CFI}=0.937 ; \mathrm{SRMR}=0.058$. 
Table 2. Demographic Characteristics of respondents.

\begin{tabular}{|c|c|c|c|}
\hline \multicolumn{2}{|c|}{ Item } & \multirow{2}{*}{$\begin{array}{c}\text { Frequency } \\
153\end{array}$} & \multirow{2}{*}{$\begin{array}{c}\text { Percent } \\
70.8\end{array}$} \\
\hline & Male & & \\
\hline Gender & Female & 63 & 29.2 \\
\hline \multirow{4}{*}{ Age } & $25-35$ years & 43 & 19.9 \\
\hline & $36-45$ years & 98 & 45.4 \\
\hline & $46-55$ years & 70 & 32.4 \\
\hline & $56-60$ years and above & 5 & 2.3 \\
\hline \multirow{2}{*}{ Staff Category } & Academic & 143 & 66.2 \\
\hline & Non-Academic & 73 & 33.8 \\
\hline \multirow{4}{*}{$\begin{array}{l}\text { Number of years } \\
\text { worked in this } \\
\text { institution }\end{array}$} & Below 1 year & 13 & 6.0 \\
\hline & Between 2-5 years & 89 & 41.2 \\
\hline & Between 6-10 years & 105 & 48.6 \\
\hline & Above 10 years & 9 & 4.2 \\
\hline \multicolumn{2}{|c|}{ Total } & 216 & 100.0 \\
\hline
\end{tabular}

Table 3. Inter-variable correlation results.

\begin{tabular}{cccccccc}
\hline & Variables & $\mathbf{1}$ & $\mathbf{2}$ & $\mathbf{3}$ & $\mathbf{4}$ & $\mathbf{5}$ & $\mathbf{6}$ \\
\hline 1 & Reward system & & & & & & \\
2 & Organizational policy & $0.397^{* *}$ & & & & & \\
3 & Work environment & $0.362^{* *}$ & $0.551^{* *}$ & & & & \\
4 & Leadership & $0.393^{* *}$ & $0.483^{* *}$ & $0.335^{* *}$ & & & \\
5 & Employee commitment & $0.533^{* *}$ & $0.558^{* *}$ & $0.540^{* *}$ & $0.595^{* *}$ & & \\
6 & Intention to stay & $0.420^{* *}$ & $0.384^{* *}$ & $0.422^{* *}$ & $0.331^{* *}$ & $0.519^{* *}$ & - \\
\hline
\end{tabular}

Note: ${ }^{* *}$. Correlation is significant at the 0.01 level (2-tailed).

Table 4. Validity and reliability analysis.

\begin{tabular}{|c|c|}
\hline Construct/Indicators/Validity and Reliability Results & Loadings (T-Values) \\
\hline $\begin{array}{l}\text { Reward system }(\mathrm{CA}=0.744 ; \mathrm{CR}=0.759 ; \mathrm{AVE}=0.517) \\
\text { - Staff are positively recognized when they come up with high-quality work } \\
\text { - The university pays a better reward package compared to other similar organizations } \\
\text { - The university cherishes individual excellence over teamwork }\end{array}$ & $\begin{array}{c}0.843(6.86) \dagger \\
0.634 \text { (fixed) } \\
0.662(6.26)\end{array}$ \\
\hline $\begin{array}{l}\text { Organisational policy }(\mathrm{CA}=0.871 ; \mathrm{CR}=0.872 ; \mathrm{AVE}=0.629) \\
\text { - Policies and procedures of the university have been helpful } \\
\text { - Progress procedures for monitoring the planned objectives of the university are reviewed periodically } \\
\text { - The current university management structure promotes our way of doing things } \\
\text { - This university has a definite vision/mission to guide its goals and aspirations }\end{array}$ & $\begin{array}{l}0.826(9.99) \\
0.765 \text { (fixed) } \\
0.817(9.88) \\
0.763(9.17)\end{array}$ \\
\hline $\begin{array}{l}\text { Work environment }(\mathrm{CA}=0.839 ; \mathrm{CR}=0.841 ; \mathrm{AVE}=0.572) \\
\text { - There is a balance between my working life and my family life } \\
\text { - In all, I see this university as a peaceful place of work } \\
\text { - Welfare of staff is regarded as the number one priority of the university } \\
\text { - As per my core task, the immediate physical working conditions are sufficient }\end{array}$ & $\begin{array}{c}0.797 \text { (fixed) } \\
0.782(9.56) \\
0.803(9.83) \\
0.630(7.49)\end{array}$ \\
\hline $\begin{array}{l}\text { Leadership }(\mathrm{CA}=0.786 ; \mathrm{CR}=0.797 ; \mathrm{AVE}=0.568) \\
\text { - The leadership practices in this university propel me to become a high performing staff } \\
\text { - Leadership practices of this university are consistent with my personal values } \\
\text { - Staff of this university are well-informed on issues that are deemed very important to them }\end{array}$ & $\begin{array}{c}0.807 \text { (fixed) } \\
0.733(8.27) \\
0.718(8.12)\end{array}$ \\
\hline $\begin{array}{l}\text { Employee commitment }(\mathrm{CA}=0.910 ; \mathrm{CR}=0.929 ; \mathrm{AVE}=0.668) \\
\text { - I have a strong feeling of belonging at this university } \\
\text { - I am very ready to give my all to help this university succeed } \\
\text { - I am always eager to let people know that I am part of this university } \\
\text { - I am always concerned about the future of this University } \\
\text { Intention to stay (CA }=0.866 ; \mathrm{CR}=0.870 ; \mathrm{AVE}=0.628) \\
\text { - I plan to work at my present job for as long as possible } \\
\text { - I am most certainly going to look for a new job in the very near future } \\
\text { - I plan to stay in this job for at least two to three years } \\
\text { - I would not like to quit this job }\end{array}$ & $\begin{array}{c}0.792(10.99) \\
0.822 \text { (fixed) } \\
0.875(12.63) \\
0.806(11.20) \\
0.689(9.40) \\
0.891 \text { (fixed) } \\
0.868(13.20) \\
0.701(9.65)\end{array}$ \\
\hline
\end{tabular}

Note: + loadings significant at $1 \% ; \mathrm{CA}=$ Cronbach alpha; $\mathrm{CR}=$ composite reliability; $\mathrm{AVE}=$ average variance extracted. 


\subsection{Common Method Bias Assessment}

As data for the study was obtained through self-reports, there is the possibility of common method bias [61]. A Harman one-factor test [62] conducted reveals a poor model fit $\left(\chi^{2}(\mathrm{DF})=1198.07(299) ; \chi^{2} / \mathrm{DF}=4.001 ; \mathrm{RMSEA}=0.145 ; \mathrm{NNFI}=0.614 ; \mathrm{CFI}=0.645\right.$; SRMR $=0.100$ ). Following the procedure of [63], however, common method bias is not a problem for our hypothesis testing as all the items were loaded on a single factor.

\subsection{Structural Equation Modeling (SEM)}

To assess the role that employee commitment plays in the relationships between organizational culture (reward, organizational policy, work environment, and leadership) and intention to stay, structural equation modeling [64] was used. The full model in Figure 2 did not have a direct path from organizational culture and commitment to intention to stay. All the fit indices were good as in Table 3, i.e., $\left(\chi^{2}(219)=292.07, p<0.11\right.$; NNFI $=0.925$; $\mathrm{CFI}=0.935 ; \mathrm{RMSEA}=0.048, \mathrm{SRMR}=0.063$ ). A series of other models were tested with reference to the full model using the method in [58].

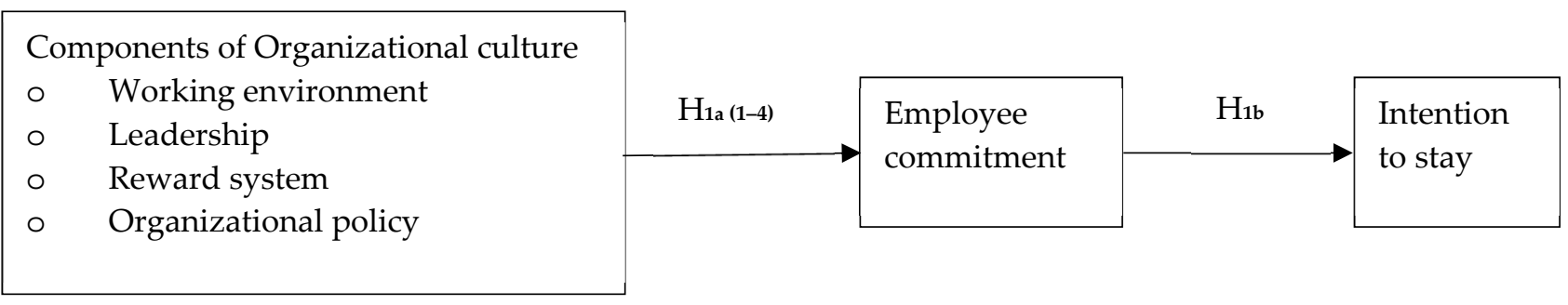

Figure 2. Model framework and hypothesis testing.

Model 1 was formulated by removing the link between organizational culture, commitment, and intention to stay. A significant change in the Chi-square is observed, interpreted to mean that the path removed, which is Hypothesis 1, was important. The process is repeated one at a time for Hypotheses 2 to 4 and labeled as Models 2 to 4 . Results for the process (in Table 5) reveal that, except for Model 2, all other models had a significant change in the Chi-square, an indication that the model fits the data well. In the next step, the full model was assessed with reference to a partial mediation model where a path from organizational culture intention to stay was included. As can be seen in Table 5, the change in the Chi-square in the full and partial mediation models was insignificant $\left(\chi^{2}=3.6, \Delta \mathrm{DF}=4, p>0.01\right)$ indicating that including the path from organizational culture to intention to stay in the full model does not make it any better.

Table 5. Structural model results alternative models.

\begin{tabular}{|c|c|c|c|c|c|c|c|c|}
\hline MODEL & $\chi^{2}$ (DF) & $\chi^{2} / \mathrm{DF}$ & $\Delta \chi^{2}$ & $\Delta \mathrm{DF}$ & RMSEA & NNFI & CFI & SRMR \\
\hline Baseline model (b) & $292.07(219)$ & 1.334 & & - & 0.048 & 0.925 & 0.935 & 0.063 \\
\hline Model 1 & $370.94(220)$ & 1.686 & $\Delta \chi_{(\mathrm{b}, \mathrm{m} 1)}^{2}=78.82 *$ & 1 & 0.069 & 0.853 & 0.872 & 0.233 \\
\hline Model 2 & $288.47(215)$ & 1.342 & $\Delta \chi_{(\mathrm{b}, \mathrm{m} 2)}^{2}=3.6$ & 4 & 0.049 & 0.926 & 0.937 & 0.058 \\
\hline Model 3 & $363.74(219)$ & 1.661 & $\Delta \chi_{(\mathrm{m} 2, \mathrm{~m} 3)}^{2}=75.27^{*}$ & 4 & 0.068 & 0.857 & 0.876 & 0.222 \\
\hline Model 4 & $295.45(216)$ & 1.368 & $\Delta \chi_{(\mathrm{m} 2, \mathrm{~m} 4)}^{2}=6.98^{*}$ & 1 & 0.051 & 0.924 & 0.935 & 0.060 \\
\hline
\end{tabular}

Note: 1. Baseline model: full mediation (i.e., no direct path from organizational culture to intention to stay); 2 . Model 1: hypothesized path constrained to zero; 3 . Model 2: partial mediation (i.e., baseline model plus direct path from organizational culture to intention to stay); 4 . Model 3: direct effect model (i.e., paths organizational culture to employee commitment was constrained to zero); 5 . Model 4: non-mediation model (i.e., paths from employee commitment to intention to stay was constrained to zero); $6 .{ }^{*} p<0.01$.

A series of alternative models were tested; we started with whether or not there is a causal relationship between organizational culture and commitment. We, therefore, fitted Model 3 where commitment and the four constructs for organizational culture (reward, organizational policy, work environment, and leadership) were set to directly influence 
intention to stay. The change in the chi-square revealed that the direct effect model (Model 3 ) was a better fit for the data than the partial mediation model (Model 2) $\left(\chi^{2}=75.25\right.$, $\Delta \mathrm{DF}=4, p<0.01$ ). We went on to test the non-mediation model (Model 4 ) to determine whether or not commitment plays a significant role in enhancing intention to stay by constraining the path from commitment to intention to stay in Model 2 to zero. The change in chi-square revealed that the non-mediation model (Model 3) was a better fit for the data than the partial mediation model (Model 2$)\left(\chi^{2}=6.98, \Delta \mathrm{DF}=1, p<0.01\right)$.

\subsection{Assessment of Hypotheses}

Hypothesis 1 seeks to determine whether or not employee commitment mediates the link between leadership and intention to stay. From Figure 3, we observe that both the hypothesized path from leadership to commitment and that from commitment to intention to stay were all significant $(\beta=0.40, \mathrm{t}=4.09, p<0.01)$ and $(\beta=0.33, \mathrm{t}=2.11, p<0.05)$, respectively. Hence, Hypothesis 1 that "Employee commitment mediates the link between leadership and intention to stay" is well supported.

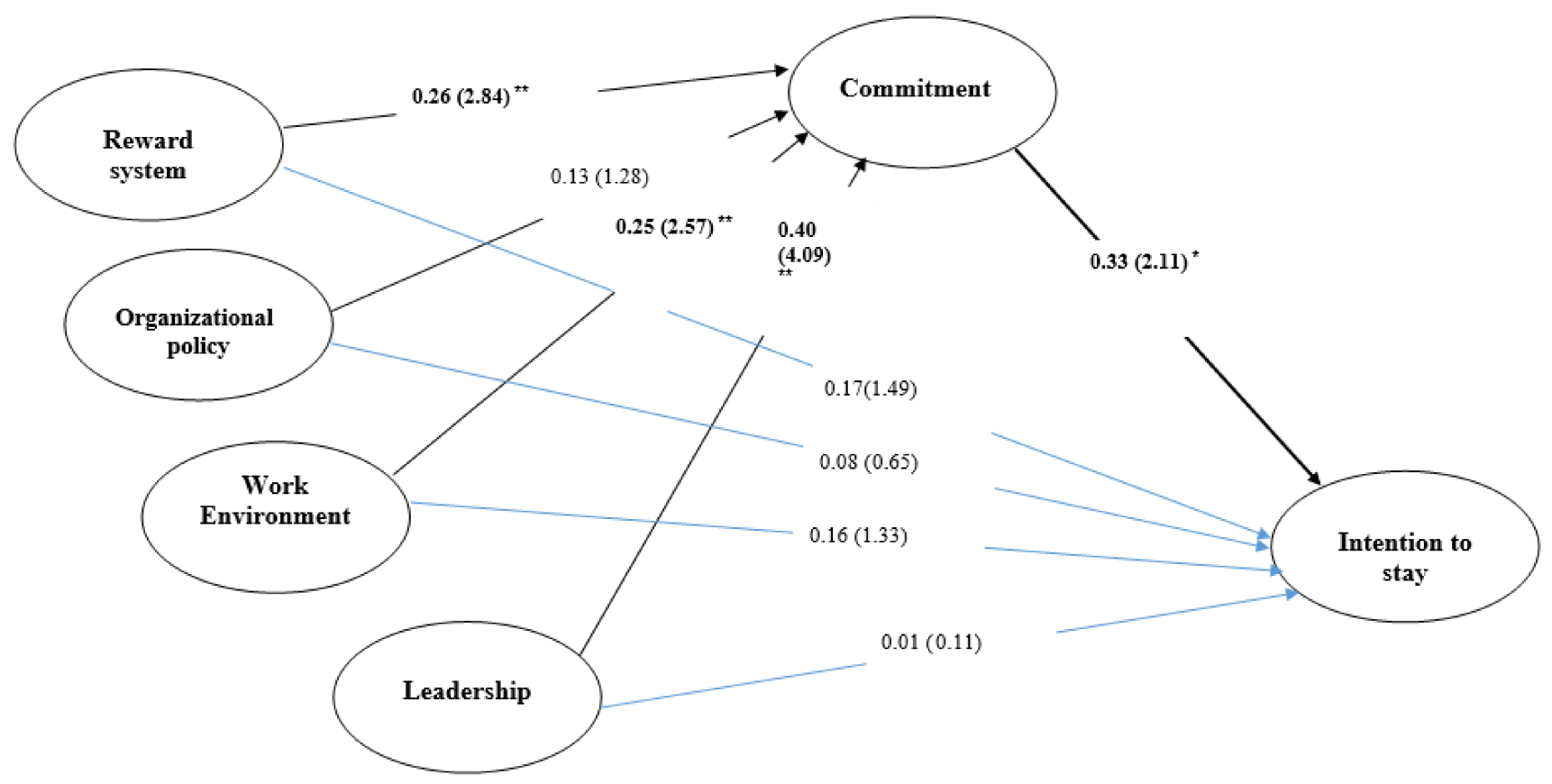

Full mediation paths:

1. Reward-Commitment-Intention

2. Work env't - Commitment - Intention

3. Leadership-Commitment-Intention

Figure 3. Final model (partial mediation). Note: Parameters are standardized estimates; with t-vales in the parentheses; ${ }^{*} p<0.05 ;{ }^{* *} p<0.01$ (one-tailed test).

Hypothesis 2 examined whether or not employee commitment mediates the link between the working environment and intention to stay. Similar to the results for Hypothesis 1 , the hypothesized path from work environment to commitment was significant $(\beta=0.25, t=2.57, p<0.01)$, and that from commitment to intention to stay was also significant $(\beta=0.33, \mathrm{t}=2.11, p<0.05)$ indicating that employee commitment mediates the link between working environment and intention to stay.

Hypothesis 3 also determined whether or not employee commitment mediates the link between the reward system and intention to stay. Similar to the results for Hypothesis 1 and 
2 , the hypothesized path from reward systems to commitment was significant $(\beta=0.26$, $\mathrm{t}=2.84, p<0.01)$, as was that from commitment to intention $(\beta=0.33, \mathrm{t}=2.11, p<0.05)$, affirming the fact that employee commitment mediates the link between reward system and intention to stay.

Hypothesis 4 states that Employee commitment mediates the link between organizational policy and intention to stay. From Figure 3, the hypothesized path from organizational policy to commitment was not significant $(\beta=0.13, \mathrm{t}=1.28)$, even though the path from commitment to intention to stay was $(\beta=0.33, \mathrm{t}=2.11, p<0.05)$. Thus employee commitment does not significantly mediate the link between organizational policy and intention to stay.

We have, therefore, generally established support for the mediating role of commitment in the link between some three components of organizational culture (i.e., reward system, work environment, and leadership) and intention to stay.

\subsection{Discussion}

This study investigated whether or not commitment mediates the relationship between some components of organizational culture and intention to stay. Organizational culture is a metaphorical force [65] and is usually determined by components such as those used in this study. It follows, therefore, that an employee's appreciation of an institution's culture becomes a direct reflection of the level of awareness of their institution's aspirations and visions [66]. They are, therefore, able to deal with external and internal issues in a manner that reflects the position of their institution and, to a large extent, positively influences the commitment of the employee [67].

This study has sufficiently demonstrated, by parameter estimates of the best-fitting model reveals of the structural equation model used, that employee commitment mediates the three components of organizational culture (i.e., reward system, work environment, and leadership) and employee intention to stay. These findings add to the rather scarce empirical results on such relationships $[15,24,25]$. Silverthorne [68] also supports our findings by establishing a strong relationship between organizational culture and employee commitment. Appealbaoum et al. [69] conclude that employee intention to stay is largely a factor of their commitment and the organization's culture, which also supports our findings. Leadership has been established by $[13,14]$ to affect the individual subcultures of staff in larger institutions such as the study institution. Brunetto and Farr-Wharton [41] also expressed that the level of job satisfaction among staff increases with supervision by immediate managers. Fang et al. [42] expressed that the leadership style of every organization can have a positive effect on work satisfaction and the commitment of the staff of that organization as well as work performance. It is instructive to note that leadership is required of all persons in a position in an organization right from the CEO down to the first-line supervisor.

Managers should restructure institutions to promote the development of the key ingredients of a cordial working environment as expressed by [32], including trustworthiness, mutual respect, shared responsibility, fairness, and caring for one another.

The selection of reward systems by the model confirms the essential influence it has on general turnover intentions even in the presence of commitment. According to [49], reward systems represent one of the most powerful elements of organizational culture as they define the employer-employee relationship and other terms and conditions, as well as the resulting benefits to the employee upon satisfactory performance. It, therefore, stands to reason that an institution seeking to enhance staff performance must pay particular attention to the organization's reward system [49].

Except for [15], who studied all three variables in one using a multidimensional measure for culture, all other researchers cited above studied the variables two at a time. They did not expand to include the various determinants of organizational culture. Thus, this study explores the determinants of culture (policy, reward, work environment, and leadership) and provides specific contributions to the literature about the relationship 
between commitment and the organizational culture determinants against intention to stay. It is also revealing that, in this study, employee commitment does not significantly mediate the link between organizational policy (a component of organizational culture) and intention to stay. The absence of significance for organizational policy is quite surprising. Chew and Chan [52] opine that organizational policy provides a sense of direction and growth for employees. This finding may occur due to a lack of a clear organizational policy or because such organizational policies were inapplicable or unknown to our participants. This may also be due to a lack of clarity on the organizational policy direction of our study institution.

These results imply that workers of our tertiary institutions feel comfortable with organizations that provide motivating reward systems, a conducive work environment, and quality leadership. In all these, commitment is seen to be a key mediator and influences the ultimate intention of the employee to remain working for the organization. Committed employees who are satisfied with the reward system, work conditions/environment, and the quality of leadership were thus most likely to remain with the organization.

A major contribution of this study is its ability to explore various components of organizational culture and establish the mediation role played by staff commitment in the relationship between such specific components of organizational culture and employee intention to stay. As of this current study only [15] had used these variables simultaneously but in a different setting other than an institution of higher learning. We have found significant support for the mediating role of employee commitment, acting as the foundational pivot between the selected components of culture and employee intention to stay. As has been strongly suggested by [70], further research should explore the interrelation between features of the components of commitment and organizational culture that may be relevant in refocusing the minds of employees who do not intend to stay. The items that measured the various constructs were long but were shortened by the reduction methods used in our analysis (CA, CEVs, CFA). The reduced scale can, therefore, be used in future related research. It will require less time for respondents to complete and will ultimately provide a high response rate.

The scope of this study is restricted to examining the relationship between the determinants of organizational culture and employee intention to stay as moderated by employee commitment using a Ghanaian tertiary institution as a case study. The findings of this study, though they may have sector-wide characteristics, are explained and generalized within the scope of the tertiary education space in Ghana only. This may be a limitation of the study. Further research into the behavior of these organizational culture determinants in many other sectors of work is important. Another notable limitation of this study is that our sample is limited to the staff of Kumasi Technical University. Future studies may consider sampling from both public and private educational institutions for some more generalizable outcomes. Since these variables (Employee commitment, organizational culture components, and intention to stay) are very dynamic and non-static, a longitudinal study would serve as an improved extension to the current study, which relied on a crosssectional study. Changes in the variables measured at one point may have some association with outcomes at a later point, and, as such, can be well studied using longitudinal data.

\section{Conclusions}

In this study, we examined the mediating role of employee commitment in the relationship between organizational cultural components such as leadership, rewards, policy and work environment of the university, and employee intention to stay. One important conclusion of this study is that a committed employee still requires a well-structured reward system, conducive work environment, and quality leadership from the management of our institutions to inform their decision to remain in the service of that organization. It can, therefore, be concluded that work environment, reward systems, and leadership should be the focus of institutional managers as they aim towards achieving lasting institutional sustainability. 
Although organizational policy provides a sense of direction and growth for employees, commitment did not act as a significant intermediate variable between organizational policy and intention to stay. From a practical standpoint, the study suggests that policymakers put significant effort into awakening the intrinsic motivation of staff in Ghanaian institutions to promote their full commitment to the institution. A strong complementary input has been made by this study, especially concerning the relationships between the studied variables, to provoke future investigation on this topic.

Author Contributions: S.A.S. conceptualization, design, data analysis, manuscript writing. M.S.A. literature review, administrative, manuscript proofreading. E.K.-O. administrative, manuscript proofreading. I.O.-A. literature review, data collection, proofreading. Y.L. research design, methodology, manuscript review, and general supervision. All authors have read and agreed to the published version of the manuscript.

Funding: This work was supported by the National Research Foundation of Korea (NRF) grant funded by the Korean government (MSIT) (No. 2019R1A2C1002408) and the Kumasi Technical University's Centre for Social Science Research (CSSR-KsTU).

Institutional Review Board Statement: Ethical review and approval were waived for this study, due to University policy for internal researchers collecting non-sensitive information.

Informed Consent Statement: Informed consent was obtained from all subjects involved in the study.

Data Availability Statement: The data presented in this study are available on request from the corresponding author. The data are not publicly available due to ethical reasons.

Conflicts of Interest: No conflict of interest.

\section{References}

1. Nohria, N.; Groysberg, B.; Lee, L.E. Employee motivation: A powerful new model. Harv. Bus. Rev. 2008, 3, 70-76.

2. Bhatnagar, J. Talent management strategy of employee engagement in Indian ITES employees: Key to retention. Empl. Relat. 2007, 29, 640-663. [CrossRef]

3. Adachi, B.; Helfrich, D.; Gretczko, M.; Schwartz, J. Human Capital Trends 2012: Leap Ahead; Deloitte Touche Tohmatsu India Private Ltd.: Mumbai, India, 2012.

4. Klein, H.J.; Molloy, J.C.; Cooper, J.T. Conceptual foundations: Construct definitions and theoretical representations of workplace commitments. In Commitment in Organizations: Accumulated Wisdom and New Directions; Klein, H.J., Becker, T.E., Meyer, J.P., Eds.; Routledge/Taylor and Francis Group: Florence, KY, USA, 2009; pp. 3-37.

5. Benkarim, A.; Imbeau, D. Organizational Commitment and Lean Sustainability: Literature Review and Directions for Future Research. Sustainability 2021, 13, 3357. [CrossRef]

6. Mathieu, J.E.; Zajac, D.M. A review and meta-analysis of the antecedents, correlates, and consequences of organizational commitment. Psychol. Bull. 1990, 108, 171-194. [CrossRef]

7. Meyer, J.P.; Becker, T.E.; Van Dick, R. Social identities and commitments at work: Toward an integrative model. J. Organ. Behav. 2006, 27, 665-683. [CrossRef]

8. Meyer, J.P.; Herscovitch, L. Commitment in the workplace: Toward a general model. Hum. Resour. Manag. Rev. 2001, 11, 299-326. [CrossRef]

9. Becker, T.E. Foci and bases of commitment: Are they distinctions worth making? Acad. Manag. J. 1992, 35, 232-244. [CrossRef]

10. Vandenberghe, C. Organizational commitments. In Commitment in Organizations: Accumulated Wisdom and New Directions; Klein, H.J., Becker, T.E., Meyer, J.P., Eds.; Routledge/Taylor and Francis Group: Florence, KY, USA, 2009; pp. 99-135.

11. Becker, T.E. Interpersonal commitments. In Commitment in Organizations: Accumulated Wisdom and New Directions; Klein, H.J., Becker, T.E., Meyer, J.P., Eds.; Routledge/Taylor and Francis Group: Florence, KY, USA, 2009; pp. 137-178.

12. Neubert, M.J.; Wu, C. Action commitments. In Commitment in Organizations: Accumulated Wisdom and New Directions; Klein, H.J., Becker, T.E., Meyer, J.P., Eds.; Routledge/Taylor and Francis Group: Florence, KY, USA, 2009; pp. 179-213.

13. Deal, T.E.; Kennedy, A.A. The New Corporate Cultures: Revitalizing the Workplace after Downsizing, Mergers, and Reengineering; Basic Books: New York, NY, USA, 2000.

14. Kotter, J.P. Corporate Culture and Performance; Simon and Schuster: New York, NY, USA, 2008.

15. Ruiz-Palomino, P.; Martinez-Canas, R.; Fontrodona, J. Ethical culture and employee outcomes: The mediating role of personorganization fit. J. Bus. Ethics 2013, 116, 173-188. [CrossRef]

16. Sroufe, R. Integration and organizational change towards sustainability. J. Clean. Prod. 2017, 162, 315-329. [CrossRef]

17. Galpin, T.; Lee Whittington, J. Sustainability leadership: From strategy to results. J. Bus. Strategy 2012, 33, 40-48. [CrossRef]

18. Norton, T.A.; Parker, S.L.; Zacher, H.; Ashkanasy, N.M. Employee green behaviour: A theoretical framework, multilevel review, and future research agenda. Organ. Environ. 2015, 28, 103-125. [CrossRef] 
19. Kim, A.; Kim, Y.; Han, K.; Jackson, S.E.; Ployhart, R.E. Multilevel influences on voluntary workplace green behavior: Individual differences, leader behavior, and coworker advocacy. J. Manag. 2017, 43, 1335-1358. [CrossRef]

20. Klijn, M.; Tomic, W. A review of creativity within organizations from a psychological perspective. J. Manag. Dev. 2010, 29, 322-343. [CrossRef]

21. Maxwell, G.; Steele, G. Organizational commitment: A study of managers in hotels. Int. J. Contemp. Hosp. Manag. 2003, 15, 362-369. [CrossRef]

22. Rizwan, M.; Shahzad, N.; Sheikh, Q.; Batool, S.; Riaz, M.; Saddique, S. Variables that Have an Impact on Employee Satisfaction and Turnover Intention. Int. J. Res. Commer. Econ. Manag. 2013, 3, 131-138.

23. Li, Y.; Yang, J.; Wu, M.; Wang, J.; Long, R. A Comprehensive Model of the Relationship between Miners' Work Commitment, Cultural Emotion and Unemployment Risk Perception. Sustainability 2021, 13, 2995. [CrossRef]

24. Andrews, M.C.; Baker, T.; Hunt, T.G. Values and person-organization fit: Does moral intensity strengthen outcomes? Leadersh. Organ. Dev. J. 2011, 32, 5-19. [CrossRef]

25. Valentine, S.; Godkin, L.; Lucero, M. Ethical context, organizational commitment, and person-organization fit. J. Bus. Ethics 2002, 41,349-360. [CrossRef]

26. Smircich, L. Concepts of culture and organizational analysis. Adm. Sci. Q. 1983, 28, 339-358. [CrossRef]

27. Alvesson, M. Understanding Organizational Culture; Sage: London, UK, 2002.

28. Weick, K.E.; Quinn, R.E. Organizational change and development. Annu. Rev. Psychol. 1999, 50, 361-386. [CrossRef] [PubMed]

29. Sackmann, S.A. Culture and performance. Handb. Organ. Cult. Clim. 2011, 2, 188-224.

30. Ashkanasy, N.M.; Wilderom, C.P.M.; Peterson, M.F. (Eds.) Handbook of Organizational Culture and Climate; Sage: Thousand Oaks, CA, USA, 2000.

31. Schneider, B.; Ehrhart, M.G.; Macey, W.H. Organizational Climate and Culture. Annu. Rev. Psychol. 2013, 64, 361-388. [CrossRef] [PubMed]

32. Schwartz, M.S. Universal moral values for corporate codes of ethics. J. Bus. Ethics 2005, 59, 27-44. [CrossRef]

33. James, H.S., Jr. Reinforcing ethical decision making through organizational structure. J. Bus. Ethics 2000, 28, 43-58. [CrossRef]

34. Brown, M.E.; Trevino, L.K.; Harrison, D.A. Ethical leadership: A social learning perspective for construct development and testing. Organ. Behav. Hum. Decis. Process. 2005, 97, 117-134. [CrossRef]

35. Northouse, P.G. Leadership Theory and Practice, 2nd ed.; Sage Publications: London, UK, 2001.

36. Trevino, L.K.; Nelson, K.A. Managing Business Ethics, 5th ed.; John Wiley: New York, NY, USA, 2011.

37. Kerr, J.; Slocum, J.W., Jr. Managing corporate culture through reward systems. Acad. Manag. Perspect. 2005, 19, 130-138. [CrossRef]

38. Eisenberger, R.; Fasolo, P.; Davis-LaMastro, V. Perceived organizational support and employee diligence, commitment, and innovation. J. Appl. Psychol. 1990, 75, 51-59. [CrossRef]

39. Greenhaus, J.H.; Callanan, G.A. Career Management; The Dryden Press: Fort Worth, TX, USA, 1994.

40. McNeese-Smith, D. Job Satisfaction, Productivity, and Organizational Commitment. J. Nurse Assoc. 1995, 25, 17-26. [CrossRef] [PubMed]

41. Brunetto, Y.; Farr-Wharton, R. Using social identity theory to explain the job satisfaction of public sector employees. Int. J. Public Sect. Manag. 2002, 15, 534-551. [CrossRef]

42. Fang, C.H.; Chang, S.T.; Chen, G.L. Applying Structural Equation Model to Study of the Relationship Model among leadership style, satisfaction, Organization commitment and Performance in hospital industry. In Proceedings of the 2009 International Conference on E-Business and Information System Security, Wuhan, China, 23-24 May 2009.

43. Berta, W.; Laporte, A.; Valdmanis, V.G. Observations on institutional long-term care in Ontario: 1996-2002. Can. J. Aging/La Rev. Can. Vieil. 2005, 24, 71-84. [CrossRef]

44. Silbert, L.T. The Effect of Tangible Rewards on Perceived Organizational Support. Management Sciences. 2005. Available online: uwspace.uwaterloo.ca/bitstream/10012/872/1 (accessed on 2 February 2021).

45. Freyermuth. Retaining Employees in a Tightening Labor Market, RSM McGladrey. 2007. Available online: www.cfo.com/ whitepapers/index.cfm/displaywhitepaper/10308654 (accessed on 26 January 2021).

46. Miller, N.; Erickson, A.; Yust, B. Sense of place in the workplace: The relationship between personal objects and job satisfaction and motivation. J. Inter. Des. 2001, 27, 35-44. [CrossRef]

47. Zeytinoglu, I.U.; Denton, M. Satisfied Workers, Retained Workers: Effects of Work and Work Environment on Homecare Workers: Job Satisfaction, Stress, Physical Health, and Retention; CHSRF FCRSS-Candanian Health Services Research Foundation, Foundation Canadienne de la Recherché sur les Services de Sante: Ottawa, ON, Canada, 2005.

48. Wells, M.; Thelen, L. What does your workspace say about you? The influence of personality, status and workspace on personalization. Environ. Behav. 2002, 3, 300-321. [CrossRef]

49. Hytter, A. Dark Side Leaders, Work Environment and Employee Health. Retrieved from Växjö University, Studies in Leadership, Entrepreneurship, and Organization. 2008. Available online: hvxu.se/ehv/forskning/hofreseminarier/2008/080514\%20 DarkSide\%20Final (accessed on 2 February 2021).

50. Normann, R. Service Management. Strategy and Leadership in Service Business; Wiley: Chichester, UK, 1986.

51. Walker, J.W. Perspectives. Hum. Resour. Plan. 2001, 24, 6-10.

52. Chew, J.; Chan, C.C. Human resource practices, organizational commitment and intention to stay. Int. J. Manpow. 2008. [CrossRef] 
53. Hewitt, P. High Performance Workplaces: The Role of Employee Involvement in a Modern Economy. 2002. Available online: www.berr.gov.uk/ files / file26555.pdf (accessed on 2 February 2021).

54. Noah, Y. A Study of Worker Participation in Management Decision Making Within Selected Establishments in Lagos, Nigeria. J. Soc. Sci. 2008, 17, 31-39. [CrossRef]

55. Colquitt, J.A.; Conlon, D.E.; Wesson, M.J.; Porter, C.O.L.H.; Ng, K.Y. Justice at the millennium: A meta-analytic review of 25 years of organizational justice research. J. Appl. Psychol. 2001, 86, 425-445. [CrossRef]

56. Mowday, R.T.; Colwell, K.A. Employee reactions to unfair outcomes in the workplace: The contributions of Adams's equity theory to understanding work motivation. In Motivation and Work Behavior, 7th ed.; Steers, R.M., Porter, L.W., Eds.; McGraw Hill: New York, NY, USA, 2003.

57. Hair, J.F.; Black, W.C.; Babin, B.J.; Anderson, R.E.; Tatham, R.L. Multivariate Data Analysis; Pearson Education: Englewood Cliffs, NJ, USA, 2012.

58. Jeevananda, S. A study on customer satisfaction level at Hypermarkets in Indian Retail Industry. Res. J. Soc. Sci. Manag. 2011, 1, $1-14$.

59. Meyer, J.P.; Allen, N. Commitment in the Workplace: Theory, Research, and Application; Sage: Thousand Oaks, CA, USA, 1997.

60. Anderson, J.C.; Gerbing, D.W. Structural equation modelling in practice: A review and recommended two-step approach. Psychol. Bull. 1988, 103, 411-423. [CrossRef]

61. Krishnan, R.; Ahmad, B.; Farihah, N.A.; Haron, H. The Effect of Employees' Perceived Fairness of Performance Appraisal Systems on Employees' Organizational Commitment. Int. J. Acad. Res. Bus. Soc. Sci. 2018, 8, 448-465.

62. Podsakoff, P.M.; MacKenzie, S.B.; Lee, J.Y.; Podsakoff, N.P. Common method biases in behavior research: A critical review of the literature and recommended remedies. J. Appl. Psychol. 2003, 88, 879-903. [CrossRef]

63. Williams, L.J.; Cote, J.A.; Buckley, M.R. Lack of method variance in self-reported affect and perceptions at work: Reality or artifact? J. Appl. Psychol. 1989, 74, 462-468. [CrossRef]

64. Mackinnon, D.P.; Lockwood, C.M.; Hoffman, J.M.; West, S.G.; Sheets, V. A comparison of methods to test mediation and other intervening variable effects. Psychol. Methods 2002, 7, 83-104. [CrossRef]

65. Pletzer, J.L.; Bentvelzen, M.; Oostrom, J.K.; de Vries, R.E. A meta-analysis of the relations between personality and workplace deviance: Big Five versus HEXACO. J. Vocat. Behav. 2019, 112, 369-383. [CrossRef]

66. Shoukat, S.; Khan, M.I. The effects of servant leadership on organizational citizenship behaviour: Moderation of proactive personality. Int. J. Sci. Res. Publ. 2019, 9, 8813. [CrossRef]

67. Delvaux, E.; Meeussen, L.; Mesquita, B. Emotions are not always contagious: Longitudinal spreading of self-pride and group pride in homogeneous and status-differentiated groups. Cogn. Emot. 2015, 30, 1-16. [CrossRef]

68. Silverthorne, C. The impact of organizational culture and person-organization fit on organizational commitment and job satisfaction in Taiwan. Leadersh. Organ. Dev. J. 2004, 25, 592-599. [CrossRef]

69. Appealbaoum, S.; Bartolomucii, N.; Beaumier, E.; Boulanger, J.; Corrigan r Dore, I.; Girard, C.; Serroni, C. Organizational Citizenship behaviour a case study of culture, leadership and trust. Manag. Decis. 2004, 42, 13-40. [CrossRef]

70. Alfes, K.; Shantz, A.D.; Truss, C.; Soane, E.C. The link between perceived human resource management practices, engagement and employee behaviour: A moderated mediation model. Int. J. Hum. Resour. Manag. 2013, 24, 330-351. [CrossRef] 